\title{
The theory of atmospheres and its applications
}

\author{
Gernot Böhme
}

Translated by A.-Chr. Engels-Schwarzpaul

1. Theory

\section{a. Origins}

It might be of interest to know how I started to grant atmospheres a systematic significance. It was in the context of my critique of ecology (Böhme 1989/1999). Ecology emerged as a science, at least in Germany, as a response to the need to engage with environmental problems, and it was tasked with providing solutions. Although interest in it was therefore from the outset determined by the context of human life, ecological theory (drawing on older approaches like Ernst Haeckel's) was developed exclusively in the natural sciences. The insights gained from this approach are no doubt very important; they also amount to a correction of traditional biology's focus on the individual organism. Considering organisms in the context of their symbioses and their biological and climatic conditions (and, from there, progressively the interplay of many organisms in a region - that is, the ecosystem) was an important scientific advance.

However - and that was our critique ${ }^{1}$ - approaches emanating purely from the natural sciences are insufficient when the human environment (Umwelt) is at issue, and the concept of ecosystem might even be misleading. For the parts of nature put in question in that instance are not determined by natural boundaries like ecosystems alone; rather, they are delineated by social and political boundaries, particularly by property boundaries. Further, those parts of nature (we ended up calling them ecological fabrics, ökologische Gefüge, see Böhme \& Schramm 1985) are not, or not only, determined by natural, that is bodily, reproduction and systemic goals arising in natural sequence, but by social and particularly economic ideas about what the respective part of nature is supposed to be: arable land, a park or recreational landscape.

It follows, then, that the scientific consideration of human environments cannot rely solely on the categories of the natural sciences but must also involve concepts from the humanities. Particularly interesting in our present context is the fact that aesthetic categories apply when dealing with human environments. By aesthetic categories, I mean everything that arises from the sensory presence of humans in their environment. In this context, the issue is no longer simply whether an environment is acceptable to humans because it accommodates the life of human organisms but also how one is in a respective environment, whether one feels comfortable or not. ${ }^{2}$

I have introduced the concept of atmosphere (Atmosphäre, see Böhme 1989/1999) to designate that which mediates the objective qualities of an environment with the bodily-sensual states of a person in this environment; the environment in its entirety generates an atmosphere in which I, as a human, feel in one way or another. In German, the word befinden expresses this well: in my state (Befinden) I sense in which environment I am located (ich mich befinde). The concept of atmosphere is, according to this etymology, a concept concerning the in-between (Zwischen): between objective conditions and subjective states, between object and subject.

In the context of developing an ecological aesthetic of nature, the introduction of the concept of atmosphere is part of wider philosophical and scientific developments. Thus, Hermann Schmitz (1964) advances a 
phenomenology of atmospheres as part of his theory of perception within New Phenomenology. ${ }^{3}$

For Schmitz, atmospheres are quasi-objective sentiments. They involve spatially extended, pathetic powers that remain undetermined. Since Schmitz, for his part, builds on Rudolf Otto's studies of the numinous (1917/2004), the experience of atmospheres is dominant in his thinking; the question is how we can speak of an aesthetic theory of atmospheres when he is concerned with an aesthetics of reception.

In a scientific context, the concept of atmosphere occurs first in psychiatrist Hubert Tellenbach's book Geschmack und Atmosphäre (Taste and atmosphere, 1968). The term taste generally refers to oral phenomena but Tellenbach is, in fact, primarily interested in olfactory atmospheres. His paradigm is nest odour (Nestgeruch), a smell that conveys to organisms, humans included, a feeling of comfort and wellbeing.

\section{b) The term atmosphere}

Originally, though, the term atmosphere was coined in meteorology to denote the upper mantle of air. Its metaphoric use, designating mood conveying spaces, goes back to the eighteenth century. The metaphorical transition from meteorology to a theory of feeling is mediated in the common idea that weather conditions can induce certain states of mind, as when a looming thunderstorm brings with it an agitated mood (Böhme 2003b). After more than 200 years of language development, the term atmosphere is so well established, in almost all European languages, to describe spatially extended moods that it is hardly recognised as a metaphor any longer and its meteorological background is almost forgotten.

From this discussion of the term and concept of atmosphere follows an initial definition: atmospheres are attuned spaces. This immediately denotes their in-between status. We are dealing here with quasi-objective sentiments, with feelings that are suspended in the air. While one might be generally inclined to regard feelings as something purely subjective, internal to the soul, atmosphere is, by contrast, something external and thereby accessible to many subjects: one can argue about the atmosphere that prevails in a space. And if one is further accustomed to regard feelings as something non-spatial and even non-localisable, atmospheres are essentially spatial; more precisely, they are spaces pregnant with a mood. It follows from these characteristics of atmospheres - namely, that they are quasi-objective and spatially extended feelings - that one can apprehend atmospheres only by entering the respective spaces.

This inference also gives a hint about how one can recognise atmospheres: the basic modes are ingression and discrepancy. Ingression refers to entering a space (be it a building or a landscape) and recognising at the threshold what mood wafts from it. Discrepancy refers to the fact that one explicitly notices atmospheres in their character when (or, particularly when) one is already immersed in a mood which is different from that wafting from the space. One is, of course, always already in spaces, and one therefore also always already participates in their mood character - as is the case, for example, with the nest odour of one's own dwelling. It is just that, then, one does not notice the atmosphere, precisely because of its ordinariness, even though one's own mood is influenced by it. The mood character of a space becomes explicit in the modes of ingression and discrepancy because it is surprisingly new and unexpected.

Thus, we have explicated the ways in which atmospheres are recognised by their characteristics. The character of an atmosphere is the mood into which I tend to be drawn when I expose myself to it: a bright valley tends to make me feel cheerful; a magnificent hall tends to put me into a festive mood; the atmosphere of a company of mourners can move me to tears. The characteristics of atmospheres can be ordered into five main groups: first, moods in their narrow sense, like serious, cheerful, 
melancholic. Second, synaesthesia, that is, states like cold, warm, soft, hard. They are called synaesthesia because they can be produced by different sensory qualities in an environment. Thus, a room can appear cool because it is entirely painted blue, or is clinically sterile, or is completely tiled, or else has a low room temperature.

A third group of characteristics are suggestive of movement, such as wide, narrow, uplifting, oppressive. Here, the geometrical forms and distributions of volumes in space, above all, make such conditions palpable. A fourth group consists of intersubjective atmospheres: a certain atmosphere always arises in the encounter of two persons, even before any conversation begins, as its background. These atmospheres are determined by a "first impression", that is by the physiognomy of a person, her or his height, volume, etc. Lastly, I want to mention conventional characteristics, such as elegant, petit bourgeois, poor, rich. They are generated by objects and symbols whose emanation is culturally conditioned. This may concern already the sensual moral effect (sinnlich-sittliche Wirkung) of colours, according to Johann W. von Goethe (2012), but it applies equally to the use of materials and, finally, symbols more specifically, for instance, Christian symbols.

And with that, we have already touched on the last, and most important point for this theory, namely, that atmospheres can be produced, and that it is possible to identify generators of atmospheres with specific characteristics. This view of atmospheres starts, in contrast to the earlier ones discussed above (which considered atmospheres from the perspective of aesthetics of reception), from an aesthetics of production. The fact that one can produce atmospheres, and that there is also a body of knowledge concerning how one can do that, turns the art of the stage set into a paradigm that can, or even must, orient any theory of atmospheres. Scenographers have always known how to generate in a performance space an atmosphere (which they often call Klima, climate) that, on one hand, attunes the audience to the events to come and, on the other, provides the actors with a resonant ground for their performance. The art of the stage set teaches us to appreciate objects and qualities, less with respect to their characteristics, than with respect to their emanation into space, namely their ecstases (Böhme 1993). Further, as particularly the developments in scenography since approximately 1900 have shown, the most important generators contributing to the realisation of atmospheres are light and sound, that is, more specifically: music and illumination.

\section{Applications}

\section{a) Scenography}

Not only is scenographic art an historical paradigm for the theory of atmospheres, it also demonstrates concretely that atmospheres can be produced and, further, that what they produce (namely, a certain mood pervading the performance space, the so-called Klima) is something quasi-objective or, better, intersubjective. For if everyone in the auditorium perceived the atmosphere on stage in a different way, the whole of scenography would be meaningless. Another historical paradigm relevant to contemporary scenography, aside from the stage, builds on the same intersubjective qualities of atmospheres: garden and landscape art. One could even interpret garden art, and particularly that of the English Garden, as the first application of a theory of atmospheres. In his five-volume Theorie der Gartenkunst (Theory of Garden Art, 1779-85), Christian C. L. Hirschfeld portrayed his subject as a practice using very specific means to create scenes in a park or garden. The term scenes indicates that scenography serves Hirschfeld as a model for garden art: namely, to create garden areas as scenes with a specific character, such as cheerful, serious, gentle, melancholic, heroic. Thus, he allocates moods to scenic arrangements and emphasises that the use value (if one can call it that) of the English Garden lies in its provision of places that provide resonance chambers for one's own moods. Important in this context, as in scenography generally, is his production 
aesthetics approach: Hirschfeld explains in detail how a natural scene can be given a characteristic mood through the use of certain plants, trees, water courses, light angles, sounds and so on.

Garden art, then, is a first application of a more general scenography. Another is the political sphere. The staging of politics, too, has a long tradition in which one has to include at least the court rituals since the Renaissance. During the Baroque period, in particular, politics were staged like theatre. For our purposes, though, it only gets serious in more recent times, with the aestheticisation of politics criticised by Walter Benjamin in his 1936 essay The work of art in the age of mechanical reproduction (1969). Benjamin focused predominantly on the fascists' parades and mass assemblies, but his critique was equally aimed at the mega events and mass rallies of Soviet socialism. In democratic states, too, politics has turned theatrical, due particularly to the mass media's central role. Here, the production of images and scenes is part of politics itself, rather than simply serving as information about politics.

So much for theatre, garden art and politics. Meanwhile, however, scenographic art has expanded to include the staging of almost all areas of life. This obviously applies to large sports events, like the Olympics and the Soccer World Cup, and to music events and discos. However, scenography has also long since reached museums and exhibitions. In these contexts, it is no longer just a matter of showing objects and art works to an audience but, rather, of stage-managing them. The issue is, then, the How of representation.

\section{b) Commodity aesthetics}

Benjamin pointed out that commodities were already as stage-managed as in a theatre, in nineteenth-century world exhibitions and the architecture of Parisian arcades around 1900: the window display as stage-space. Around 1970, an explicit commodity aesthetics began to take shape on the background of Benjamin's earlier investigations in the fragments of his Arcades work (Benjamin 1999). Wolfgang Fritz Haug, in particular, demonstrated in his book Kritik der Warenästhetik (Critique of commodity aesthetics, 1972) that, under conditions of increased capitalist competition, commodities appear in a getup designed to render them attractive in a sales context; they also imply, though, a promise of use value that far exceeds their real use value and that is therefore illusory. Today, we have advanced far beyond these beginnings of a critique of commodity aesthetics, along with the enormous expansion undergone by commodity aesthetics itself.

The most remarkable dimension of this expansion is the spread of commodity aesthetics beyond its point of origin, the market, to take hold of the productive sector. There are cases where production itself is stage-managed and thereby comes under the sway of aesthetic imperatives. The main example would have to be the Transparent Factory (Gläserne Manufaktur) in Dresden. Here, in the so-called Great Garden (a Baroque garden, it should be recalled), Volkswagen have built a plant for the final assembly of their model Phaeton. Before the eyes of the visitors, who follow the process from behind the glass partitions of the integrated restaurant, the production of motor vehicles takes place as an aesthetic performance: the factory floor of parquet, the workers in white suits and kid gloves, the interplay between conveyor belt, workers and the silently gliding carts for tools and parts ... a Polonaise.

At the other end of the spectrum, commodity aesthetics expand - and this may be even more significant than their penetration of the sphere of production - into consumption. While it was once possible to distinguish, with Marx, two values in the commodity, namely the use value and the exchange value, more recently, and in the wake of the expansion of commodity aesthetics into the use context, a third value has taken shape, which I have called stage value (Inszenierungswert, see Böhme 2003a). For it is no longer the case that the commodities one has purchased are either consumed or used instrumentally in some work or circulation context; rather, they now serve, for the 
most part, as furnishings for life and as props for the stage-management of a particular lifestyle. The aesthetic value of a commodity, which in an exchange context initially served the realisation of its exchange value, is now also significant in the context of use. Whereas Haug still believed that, post-purchase, the commodity is divested of its exchange value along with its packaging, as it were, we can say that, in our current contexts of use, the aesthetic appearance of a commodity is decisive; that is to say, its aesthetic appearance creates, in a sense, a new use value. We, the consumers, stage ourselves (or our lives) via commodities. In the process, commodities not only serve as status symbols (as was believed in an earlier phase) - they do that, too, of course - rather, with their help, the consuming individuals endeavour to position themselves properly in the limelight (Mahayni 2014, forthcoming).

\section{c) Advertising, marketing}

The stage-management of commodities, already observed by Benjamin, has fundamentally altered advertising and marketing strategies since approximately 1900 . Whereas then, and for some decades thereafter, the advertisement for a commodity always highlighted the solidity of its production and material, along with its usefulness or use value, we can see today that individual commodities normally no longer appear separately in commercials and advertisements but, rather, only as components of a scene. Thus, it takes some effort to discover in a commercial representing a picnic or travel scene the Vuitton bag, which is the object of the advertisement. Likewise, one discovers almost in passing - as an ingredient, as it were - the beer bottle in a sailor's hand during an animated and adventurous yachting scene, an advertisement for Becks beer. This type of advertising invokes the idea that consumers do not simply acquire an object they want to use when they purchase a commodity, or a substance providing nourishment; rather, in buying this commodity, they want to align themselves with a particular group or social stratum, or distinguish themselves from other groups or individuals (Böhme 2008). What is presented in this type of advertising is the commodity's stage value, completely irrespective of its use value. And the staging is not simply about consumption: it concerns the contribution of consumer goods to the production of a particular living atmosphere.

\section{d) Art}

The staging of art works, too, is an application of the aesthetic theory of atmospheres - I have already mentioned this. From this perspective, though, a new way of looking at art arises. Thus, the 1995 exhibition Das Bild und sein Rahmen (The image and its frame) in Amsterdam represented a critical pointer to the way in which established art history traditionally pretended that it was possible to consider the art work in itself (Mendgen 1995). This assumption was not only held in the discipline of art history itself, of course; it was applied to reproductions of art works in books or during lectures where, as a rule, the naked art works were displayed. Meanwhile, though, the influence of an aesthetic of atmospheres has expanded, and this has led to a relativization of conventional modes of accessing art works, through semiotics or hermeneutics. The latter always endeavoured to find meaning or intent in a work of art: singular elements within an image or the image as a whole refer, according to this mode of access, to something else, namely the meaning. Hermeneutics is intimately linked to semiotics, except that, as an art of interpretation, it also brings into play the historical periods, the history of a sign's effects and reception (Wirkungsgeschichte, Gadamer 1975), as well as its intertextuality. By comparison with semiotics and hermeneutics, structuralism already introduced a novel aspect, as it were, by appreciating individual signs (or signifiers) appearing in an art work as belonging to a system of signs, or better, as part of the play between them. An example is the iconology proposed by Aby Warburg, but also the depth hermeneutics (Tiefenhermeneutik) following on from Jacques Derrida. From a radically 
new perspective, the aesthetics of atmospheres enquires into the experiences a visitor might have in the presence of the art work. This development, of course, is also influenced by the fact that museum and exhibition guides, who bombard their customers with information about the artist and the history of reception, deprive them of their own experiences in front of the art work. On the other hand, contemporary mass exhibition strategies do not target, with their exhibits, a traditional, educated middle-class (Bildungsbürgertum) but often an audience which is no longer able to ask questions about the meaning of art works. Whatever the frameworks of these recent developments, one can say that the aesthetics of atmospheres has opened up a new feature of art works, namely, the experiences that can be had before and in the presence of a work of art.

If the aesthetics of atmospheres open up a new dimension for the consideration and discussion of art works, one can also observe that particular types of art works and trends are beginning to orient themselves towards that dimension. Thus, there are contemporary art works that can only be accessed through corporeal presence. The designation performative art emphasises the performative and event character of such works. Because the expression performative art highlights the temporal element, though, it does not include all directions along which artists align themselves explicitly with experiential values: one has to be present at the time at which the art work is performed. In the case of some other works within this genre, this temporal factor does not carry as much weight as a spatial factor: one has to be in the place where the artwork is, or is performed, in order to be able to experience the work adequately. This is particularly the case with installation art and land art.

Installation art is concerned with concrete, that is, for example, sculptural arrangements or with the design of total environments; land art concerns the staging of landscapes or the embedding of art works into natural scenes. The latter may well include performative aspects, as in the works of Andy Goldsworthy. In sound art, the interpenetration of spatial and temporal presence is even stronger. Sound installations create acoustic environments and thereby spatial atmospheres. Earlier, in the discussion of the art of scenography, I already pointed out that sound, noise and music are amongst the main generators of atmospheres. In sound-installation, two developments concur: on the one hand, the Soundscape movement (Murray Schafer) is concerned with the exploration of existing acoustic landscapes, and, on the other, the concrete music of, for instance, John Cage, seeks to create acoustic landscapes or, at least, environments, as it were. Here, in the realm of the acoustic, it becomes particularly clear that the proper evaluation of a work of art consists of exposing oneself to the atmosphere that is, in this case, created by acoustic means.

Meanwhile, the experiences gleaned from the Soundscape movement and acoustic installations have shown us how important acoustic environments are for the wellbeing of individuals and humans generally. Thus, the efforts to achieve good lighting design in cities have now been joined by efforts to achieve a 'tuning of the city (see Schafer 1994) through sound design.

\section{Conclusion}

Thus, we have come full circle. The theory of atmosphere amounts, on the side of social practice, to the stage management of everything and anything: from commodity aesthetics to the staging of our selves in terms of a particular life style; to the staging of art and art as staging; to the staging of politics and whole architectural complexes, from shopping malls to cities. The theory of atmospheres clarifies what is at stake, namely: the staging serves to create atmospheres that permit a specific affective participation in our world. The increasing contribution of an aesthetics of atmospheres to theory corresponds to the immense expansion of artful staging, far beyond the realm of theatre. The common key in both is the aesthetic economy, which takes as its theme questions concerning the dominance of stage value vis à vis use value and exchange value in our present era of advanced capitalism (see Böhme 2003a). 


\section{References}

Benjamin, W. (1969). The work of art in the age of mechanical reproduction. In H. Arendt (Ed.), Illuminations (pp. 217251). New York, NY: Schocken.

Benjamin, W. (1999). The Arcades Project (H. Eiland \& K. McLaughlin, Trans.). Cambridge, MA: Harvard University Press.

Blume, A. (2010). Hermann Schmitz (1928-). In H. R. Sepp \& L. Embree (Eds.), Handbook of Phenomenological Aesthetics (pp. 307-309). Dordrecht, Netherlands: Springer

Böhme, G. (1993). Die Ekstasen des Dinges. Ontologie und Ästhetik der Dinghaftigkeit. In M. Grossheim \& H.-J. Waschkies (Eds.), Rehabilitierung des subjektiven (pp. 45-64). Bonn, Germany: Bouvier.

Böhme, G. (1999). Für eine ökologische Naturästhetik. Frankfurt/M, Germany: Suhrkamp (Original work published 1989).

Böhme, G. (2003a). Contribution to the critique of aesthetic economy (Zur Kritik der ästhetischen Ökonomie). Thesis Eleven, 73(May), 71-82.

Böhme, G. (2003b). Das Wetter und die Gefühle. Für eine Phänomenologie des Wetters. In B. Busch (Ed.), Luft (pp. 148-161). Bonn, Germany: Kunst- und Ausstellungshalle der BRD.

Böhme, G. (2008). Der Geschmack des Gewöhnlichen. Über Distinktionsschicksale im Zeitalter der ästhetischen Ökonomie. In G. Kohler \& S. Müller-Doohm (Eds.), Wozu Adorno? Beiträge zur Kritik und zum Fortbestand einer Schlüsseltheorie des 20. Jahrhunderts (pp. 235-251). Weilerswist, Germany: Velbrück.

Böhme, G., \& Schramm, E. (Eds.). (1985). Soziale Naturwissenschaft. Wege zur Erweiterung der Ökologie. Frankfurt/M., Germany: Fischer.

Gadamer, H.-G. (1975). Truth and method. New York, NY: The Continuum Publishing Corporation.

Haug, W. F. (1972). Kritik der Warenästhetik. Frankfurt a.M, Germany: Suhrkamp.

Hirschfeld, C. C. L. (1779-85). Theorie der Gartenkunst. Leipzig, Germany: M. G. Weidmann Erben und Reich.

Mahayni, Z. (2014 forthcoming). Dialektik zwischen Individualität und Konsum. In G. Böhme \& U. Gahlings (Eds.), Wie leben wir in dieser Gesellschaft? Bielefeld, Germany: Aisthesis Verlag.

Mendgen, E. (1995). In Perfect Harmony. Bild und Rahmen 1850-1920 (Catalog). In Van Gogh Museum Amsterdam (Ed.). Zwolle, Netherlands: Waanders Uitgevers.

Otto, R. (2004). Das Heilige: Über das Irrationale in der Idee des Göttlichen und sein Verhältnis zum Rationalen. München, Germany: Beck. (Original work published 1917)

Schafer, R. M. (1994). The soundscape: Our sonic environment and the tuning of the world. Rochester, VT: Destiny Books. (Original work published 1977)

Schmitz, H. (1964). System der Philosophie. Bd. IIl.1 Die Wahrnehmung. Bonn, Germany: Bouvier.

Schmitz, H. (2011). Emotions outside the box - The new phenomenology of feeling and corporeality (Trans. Rudolph O. Müllan and Jan Slaby). Phenomenology and the Cognitive Sciences, 10(2), 241-259.

Tellenbach, H. (1968). Geschmack und Atmosphäre. Medien menschlichen Elementarkontaktes (Taste and atmosphere. Media of elementary human contact). Salzburg, Austria: Otto Müller Verlag.

von Goethe, J. W. (2012). Theory of colours. New York, NY: Courier Dover Publications. 


\section{Endnotes}

1. By "our",I mean the working group Soziale Naturwissenschaften (Social Natural Sciences), see Gernot Böhme and Engelbert Schramm (1985).

2. The term befinden brings several dimensions into play: to be located, to feel, to find oneself placed, but also to decide.

3. Schmitz called his work New Phenomenology to distinguish it from versions of classical phenomenology like Edmund Husserl's. Central to New Phenomenology is the concept of Leib, the felt body (Körper is the material, observed and often objectified body). Husserl, Heidegger and, to a lesser extent perhaps, Merleau-Ponty, have in his view not fully overcome the mind/body dualism at the basis of Western philosophy since $40 O B C$. Schmitz, then, is particularly interested in the interconnections between bodily experience, subjectivity and existence, "the shared sensible space around us: significant situations, affective atmospheres, meaningfulness, concrete possibilities" (Slaby and Müllan in their introduction to Schmitz 2011, p. 244; see also Blume 2010, pp. 307-309). 